\title{
An investigation of textbooks used to teach Turkish as a foreign language with Rasch measurement model and Maxqda
}

\author{
Nurşat Biçer ${ }^{\mathrm{a} *}$ (iD), Veli Batdı ${ }^{\mathrm{b}}$ \\ ${ }^{a}$ Kilis 7 Arallk University, Kilis 79000, Turkey \\ ${ }^{b}$ Kilis 7 Aralık University, Kilis 79000, Turkey
}

\section{APA Citation:}

Biçer, N., \&Batdı, V. (2019). An investigation of textbooks used to teach Turkish as a foreign language with Rasch measurement model and Maxqda.Journal of Language and Linguistic Studies, 15(4), 1269-1286.

Submission Date: 01/08/2019

Acceptance Date:06/11/2019

\begin{abstract}
This study aims to investigate textbooks used to teach Turkish as a foreign language according to Turkish lecturers' perspectives. Within this scope, these textbooks were evaluated in terms of the characteristics they possess. The study benefited from qualitative and quantitative approaches. The Rach measurement model was used in the quantitative and case study was used in the qualitative part. The perspectives of 54 lecturers working at Turkish education centers of universities in Turkey were obtained and 32 of them were used in the study. The Textbook Evaluation Scale developed by Batdı (2010) was used to collect the quantitative data of the study. A semistructured interview form developed by the researchers was used to collect the qualitative data. Rasch and content analysis were used to analyze the data. Codes and themes were revealed using Maxqda software while conducting the content analysis. Excerpts from the interviews were included to corroborate the participants' assessments. At the end of the study, the general characteristics of the textbooks used to teach Turkish as a foreign language were identified and the positive and negative attributes were determined. The different analyses conducted indicated that the books of Yediİklim and İstanbul have positive characteristics compared to the other books.
\end{abstract}

(C) 2019 JLLS and the Authors - Published by JLLS.

Keywords:Turkish education; textbooks; Turkish teaching for foreigners; Rasch analysis

\section{Introduction}

Textbooks, which are accepted as the fundamental material for language teaching, should have qualities that can meet students' interests and needs. The design process of textbooks should consider a multi-disciplinary approach.

A textbook is evaluated in terms of the application of inputs presented, functional use, and the appropriateness of the activities (Williams, 1983). A textbook should offer a regular outlook within a particular system in order to teach information (Richaudeau \& Gauquelin, 1997, as cited in Ömeroğlu, 2016). Textbooks can play a facilitating role for students in acquiring knowledge (Bayezit \& Çubukçu, 2015). In addition, textbooks contribute to the process of constructing knowledge in terms of standardizing teaching, supporting this standardization, using time efficiently, and using different

\footnotetext{
* Corresponding author. Tel.: +0-538-423-4282

E-mail address: nursatbicer@gmail.com
} 
teaching methods (Richards, 2001). Textbooks play a significant role in valuing school and extracurricular time; however, advanced technological opportunities have reduced the effect of textbooks. Nevertheless, they are still an indispensable source of teaching processes (Çelik \& Gülcü, 2016). Chambliss and Calfee (1998) state that textbooks have positive effects on the education levels of learners. A well-designed textbook enriches the learning process by providing a transition between the students' capacity of perception and the teachers' level of teaching.

Teaching Turkish to foreigners has been increasingly developed in recent years. Turkish language is becoming more recognized throughout the world. This development is achieved primarily with textbooks designed to teach Turkish to foreigners in Turkish Education Centers (TEC). Textbooks are used as an important source in teaching Turkish both as a mother language and a foreign language (Gün, Akkaya, \& Kara, 2014).

In language teaching, textbooks guide the learners by strengthening written and verbal communication and play a directive role for teachers (Cunningsworth, 1995). Consequently, it becomes important to determine which characteristics textbooks should possess in order to make positive contributions to teaching and learning processes (Özdemir, 2013). A needs analysis can be carried out to determine the objectives of textbooks to facilitate and accelerate the learning process in foreign language teaching (Akbulut \&Yayl1, 2015). Analyses should be made within the scope of characteristics such as target age group and mother language (Biçer \& Kılıç, 2017). Textbooks, as learning material, should facilitate the roles of educators and students, affect learning in a positive way, and be appropriate to the needs and level of learners (Fidan, 2016) to promote and sustain language policies. The language of course materials should be appropriate to the students' language level. Therefore, a primary consideration is to design materials at the appropriate level of the vocabulary level of students at this stage (Özdemir, 2013). Developing basic language skills is important in textbooks to provide quality contributions in teaching Turkish to foreigners (Karababa \& Üstünsoy Taşkın, 2012). Additionally, textbooks should be accessible, be composed of texts that are appropriate to themes and topics with accurate visuals, be consistent with the student workbook, and provide an assessment of students' learning (Göçer, 2007) for students to learn Turkish effectively. Moreover, textbooks should further benefit from influences in the fields of psychology, linguistic and educational sciences (Lightbown \& Spada, 2006).

The Common European Languages Framework Program recommends that textbooks have a content that can motivate in-class activities and strategies, as well as learning objectives, and methods for students' application (Council of Europe, 2001). It is important to take the preliminary steps to eliminate the problems students and teachers encounter in the classroom with textbooks. In addition, students should be provided with a rich content considering different language teaching methods.

\subsection{Literature review}

The different characteristics of textbooks designed to teach Turkish as a foreign language have the aim of effectively teaching Turkish (Biçer \& K1lıç, 2017). Fuller (2001) states that while learning a foreign language, the use of quality materials related to the target language, different sources, and auditory elements enhances the learning process. The increasing number of textbooks enhances teaching Turkish to many foreign students in Turkey and abroad. Each book has particular features and it is of critical importance to know how this is reflected in practice and how this is perceived by the Turkish lecturers. Literature shows studies addressing these questions. Göçer (2007) investigated textbooks used to teach Turkish as a foreign language in terms of measurement and assessment. Özdemir (2013) conducted a study drawing attention to the functional characteristics of textbooks. Karababa and Üstünsoy Taşkın (2012) made a review of textbooks in terms of teachers' perspectives. Gün, Akkaya, 
and Kara (2014) investigated how textbooks are perceived by university instructors. Demir (2015) conducted a study on the qualities that a textbook should possess. Kilınç and Yenen (2015) made an investigation of textbooks used to teach Turkish to foreigners from university instructors' perspectives. Biçer and Kılıç (2017) investigated textbooks used in Turkish courses for Syrian students from teachers' perspective.

\subsection{Purpose and significance of the study}

The most important element of teaching Turkish as a foreign language is textbooks. Therefore, they should be designed considering characteristics such as relevance to students, conveying the objectives quickly, being appealing to look at, and equally processing the four basic language skills. When the related literature was reviewed, prominent aspects from different studies are noteworthy. These different aspects are as follows: designing books from simple to complex, from easy to difficult, providing opportunities to implement what is learned, being relevant to daily life, and having essential topics. A textbook should possess these characteristics; however, the textbooks used to teach Turkish to foreigners has become an enigma. Although different studies investigating this issue were encountered in the literature, the current study provided a two-way analysis of this issue using the Rasch and Maxqda software, which is unique. No study investigating the most widely used textbooks from teachers' perspectives with the Rasch model and supported with qualitative documents was encountered in the literature. Therefore, the current study is original and can contribute to the field.

This study compared İstanbul-A1, İstanbul-A2, Yedi İklim-A1, Yedi İklim-A2, Gazi-A1, Gazi-A2 and Yeni Hitit-1 textbooks which are widely used to teach Turkish to Foreigners (TTF). This study used both qualitative and quantitative approaches and is of critical importance in terms of revealing the qualities of the textbooks and illustrating the perceptions of lecturers. The contributions of this study expect to eliminate deficiencies in the textbooks.

\subsection{Research questions}

The main purpose of this study is to investigate the textbooks used to teach Turkish as a foreign language according to lecturers' perspectives using the Rasch measurement model and Maxqda software. This study will seek to answer these research questions:

1. A general analysis of the participants' perspectives regarding the textbooks, evaluators' rigorousness/generousness, and item difficulty analysis were made with the Rasch Measurement Model

2. Perspectives on the book set that best reflect the TTF objectives, suggestions regarding the TTF book and the investigation of language skills in the TTF book sets were investigated using Maxqda software.

\section{Method}

This study was carried out in two dimensions that are qualitative and quantitative. This design enables an in-depth analysis of the research problem investigating both objectively through numerical values and naturally through the subjective interpretation of participants' direct excerpts or behaviors. In this respect, Rasch measurement model was used to analyze the data on the participants' perspectives about the textbook sets used to Teach Turkish to Foreigners (TTF). The Rasch model is defined as a model that describes the probability of the accuracy of an answer to the approval of an item on a linear scale with the relative distance between the item and the participant position. That is to say, participants' answers to any item are investigated by squaring the difficulty/easiness level of items in the evaluation 
and the scores of the elements who are assessed on the same plane. In addition, the difference between the participant's answer to the item (observed score) and expected answer (expected score) is considered in the model (Tennant \& Conaghan, 2007). On the other hand, the participants' perspectives regarding the sets used in TTF were obtained in the qualitative part and their perspectives were analyzed using the Maxqda-11 software in accordance with the case study design. The case study can be explained as a qualitative approach that is based on very firm evidence and requires in-depth investigation (Y1ldirım \& Şimşek, 2008).

\subsection{Participants}

Data were collected from 54 Turkish lecturers working at Turkish Education Centers (TEC) of various universities in Turkey on a voluntary basis. The data of 32 lecturers who completed the scoring of all teaching sets were included in the Rasch analysis dimension. These participants were assigned as evaluators in the Rasch analysis. On the other hand, 48 participants who were thought to be diverse and qualified to represent the entire population were selected to obtain their perspectives for the qualitative part. Excerpts from these participants were included in the study and particular codes were used to indicate these participants throughout the study (e.g., P4m: A male participant with the number four; P12f: A female participant with the number 12).

\subsection{Data collection procedures and data analysis}

Within the scope of the Rasch model, the study has three facets: I) the evaluators consisting of temporary Turkish lecturers ( $\mathrm{n}=32$ ); II) 26 items used to evaluate TTF sets; III) TTF book sets [İstanbulA1 (IA1), İstanbul-A2 (IA2), Yedi İklim-A1 (YA1), Yedi İklim-A2 (YA2), Gazi-A1(GA1), Gazi-A2 (GA2), Yeni Hitit-1 (HA1)]. The Textbooks Evaluation Scale developed by Batd1 (2010) in his master's thesis was used to collect the quantitative data. The Cronbach Alpha coefficient of the scale was found to be .82 , which indicates that the scale is reliable. The scale was designed as a five-point Likert-type scale where items range from "mostly agree" to "never agree". In order to evaluate the textbooks used to teach Turkish to foreigners, 14 field experts working at the TEC of the universities were consulted and the content validity ratio (CVR) and content value index (CVI) were recalculated. The results were presented. The items were evaluated by the experts in terms of their appropriateness level and each item was coded with " $1=$ not appropriate, $2=$ partially appropriate, $3=$ mostly appropriate, $4=$ very appropriate" (Davis, 1992). CVR is calculated by subtracting one from the division of the number of the experts who indicate the essential opinion by the number of all experts who indicate their opinion. Veneziano and Hooper (1997) stated the minimum values provided for the ease of calculation at the .05 significance level. Therefore, the information on the significance of the items can be obtained according to the number of experts who express an opinion about the items. In this respect, the raw data obtained after administrating the scale to the evaluators were analyzed using the FACETS analysis software.

Furthermore, the qualitative data were collected by a semi-structured interview form developed after reviewing the related literature and consulting the opinions of experts. The experts included two associate professors from the Department of Educational Sciences, five doctoral instructors from the Turkish education department, three research assistants, and four lecturers. The questions on the form were restructured based on the experts' suggestions for clarity in the purpose of the study. Experts' opinions were consulted to detect the items' fitness for the purpose and their level of representation of the targeted measurement field (Karasar, 2008). Data obtained from the participants' interview were analyzed using the Maxqda software. Maxqda software provides opportunities to reveal related codes and themes. Then, it creatively determines the relationship with the ideas revealed by questioning the data set (Lewins \& Silver, 2008). The data were analyzed based on content. Content analysis is a widely used qualitative research technique used to derive semantic interpretations from textual data; therefore, 
revealing interpretations appropriate to a naturist paradigm. At the end of the content analysis, coding schemas are formed with the analysis and interpretation of keywords or content (Hsieh \& Shannon, 2005).

\subsection{Validity and reliability}

The Cronbach coefficient of the scale was found to be .82 , which indicates that the scale is reliable in the quantitative dimension. The CVR and CVI values were found to be 0.51 and 93.5 , which corroborated the reliability of the scale. In the qualitative part of the study, the content analysis of the participant forms was read by two researchers separately and the related codes and themes were obtained. The researchers paid attention to the consistency of the codes. Fit values of the codes developed were investigated for the validity of the scale. Cohen Kappa values (Viera \& Garrett, 2005) were calculated for each theme and a good fit between .717 and .809 was determined (Appendix-1). In order to ensure the internal reliability, excerpts from the participants' perspectives were stated with the codes indicating the participants. In the validity (credibility) dimension of the study, strict attention was paid to the experts' opinions and the results' consistency with the conceptual framework.

\section{Results}

\subsection{Rasch analysis results on TTF books}

The participating teachers' perspectives on the books sets (İstanbul, Yeni Hitit, Gazi, Yedi İklim) in TTF were analyzed using the Rasch measurement model with multiple facets. The facets used in the study were: book sets used in TTF (coded as IA1, IA2, YA1, YA2, GA1, GA2 \& HA1) evaluators' rigorousness/generousness, and appropriateness of items used in the measurement tool. In addition, general information regarding the relevant facets was given in the calibration map presented in Table 1. According to this, the most qualified books set (IA1 and IA2) was located at the top and the least qualified book set (HA1) was located at the bottom. Besides, the most generous evaluators (J9 and J12) were ranked from the most generous to the most rigorous in the evaluator column from top to bottom. Similarly, the most difficult materials were presented at the top, while the least difficult was presented at the bottom. 
Table 1. Data calibration map

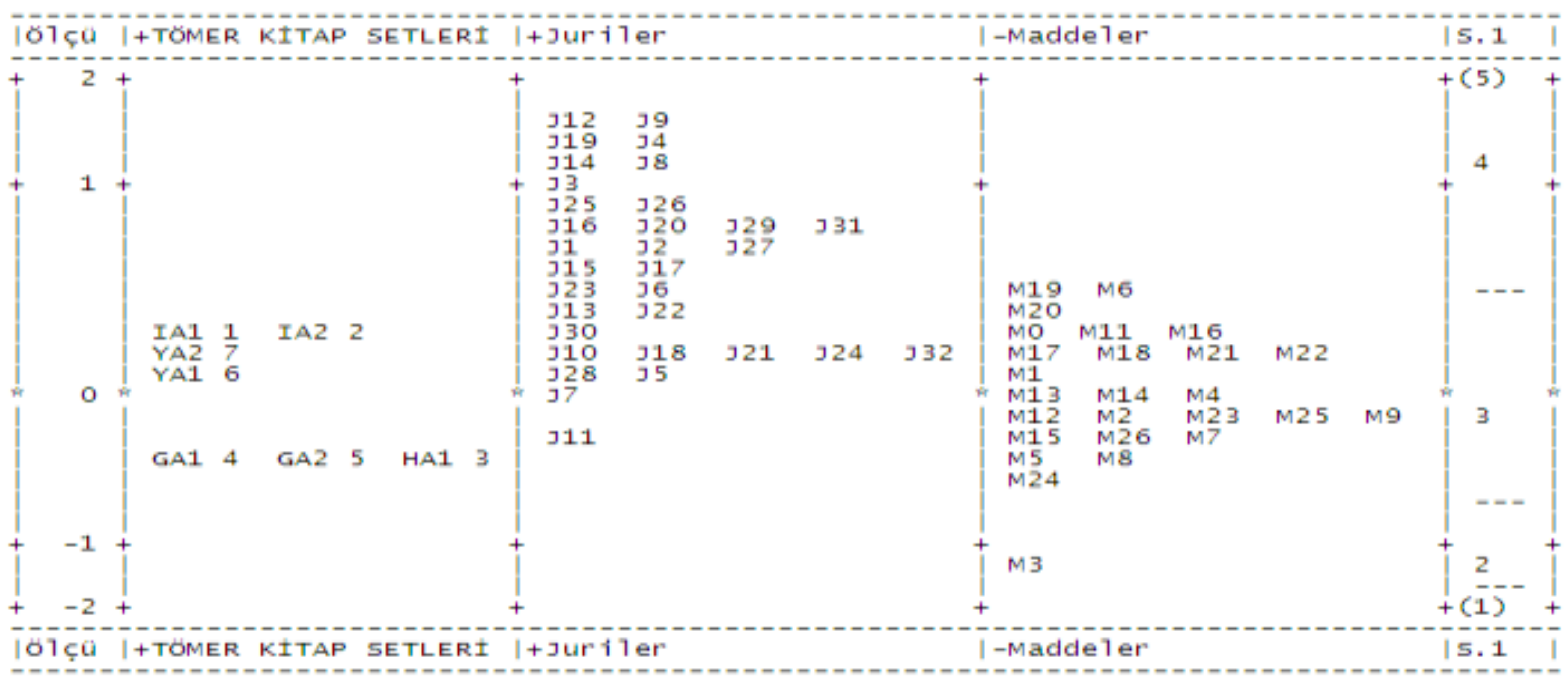

Table 1 illustrates the general analysis carried out on the calibration map. According to the participants' evaluations, IA1 and IA2 textbooks have higher quality and GA2, GA1 and HA1 textbooks have lesser quality. When the column of the items was investigated, it was determined that the item I6 ("There are objectives on the computer-aided project and research") is the hardest item and that the item I3 ("There exists a set (textbook, workbook, CD)") is the easiest item. In addition, among the evaluators, $\mathrm{J} 9$ and $\mathrm{J} 12$ were the most generous and $\mathrm{J} 11$ and $\mathrm{J} 7$ were the most rigorous. Table 2 presents the measurement report regarding TTF textbooks.

Table 2. TTF textbooks measurement report

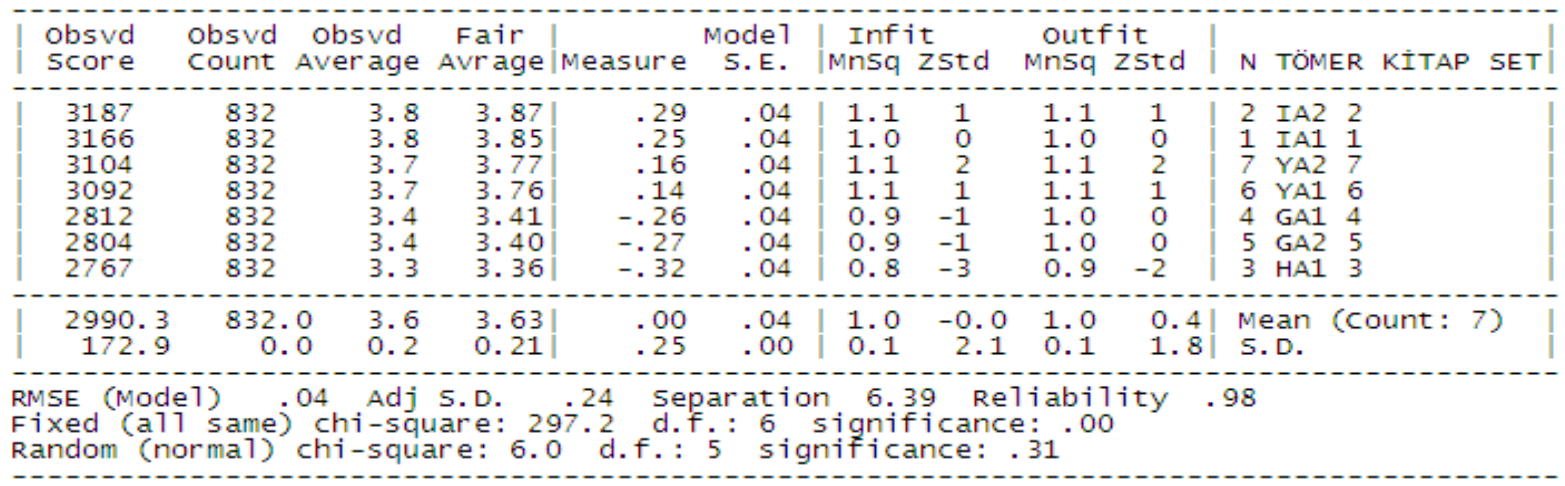

Table 2 presents a detailed measurement report on the effectiveness of TTF textbooks. As the table indicates, the reliability coefficient in the Rasch analysis was found to be 0.98 , which shows the reliability of TTF textbooks. In addition, a significant difference was determined among the aforementioned textbooks $\left(x^{2}=297.2, s d=6, p=0.00\right)$. When the information on the qualities of TTF textbooks was analyzed in detail, the standard error value (RMSE: Root Mean Square Standard Error) related to the logit values of the textbooks' qualities was found to be 0.04 , which indicates a quite low standard error. The standard deviation adjusted considering this error ratio was also below the critical value of $1.0(0.24)$. In this respect, the general order of the TTF textbooks from highest to lowest quality was IA2, IA1, YA2, YA1, GA1, GA2 and HA1, which was presented in the table. 
Table 3. Comparison of evaluators in terms of generousness/rigorousness

\begin{tabular}{|c|c|c|c|c|c|c|c|c|}
\hline $\begin{array}{l}\text { Obsvd } \\
\text { score }\end{array}$ & $\begin{array}{l}\text { obsvd } \\
\text { count }\end{array}$ & $\begin{array}{l}\text { obsva } \\
\text { Average }\end{array}$ & $\begin{array}{l}\text { Fair } \\
\text { Avrage }\end{array}$ & IMeasure & $\begin{array}{l}\text { Mode? } \\
\text { S. E. }\end{array}$ & $\mid \begin{array}{l}\operatorname{Inf1} t \\
\text { Mnsq Zsta }\end{array}$ & $\begin{array}{l}\text { outf } 1 \tau \\
\text { Mnsq zstd }\end{array}$ & NU Jürt \\
\hline $\begin{array}{l}752 \\
751 \\
744 \\
739 \\
733 \\
728 \\
713 \\
704 \\
700 \\
689 \\
686 \\
685 \\
681 \\
679 \\
670 \\
667 \\
654 \\
649 \\
638 \\
633 \\
632 \\
621 \\
602 \\
598 \\
593 \\
593 \\
590 \\
589 \\
570 \\
568 \\
564 \\
517\end{array}$ & $\begin{array}{l}182 \\
182 \\
182 \\
182 \\
182 \\
182 \\
182 \\
182 \\
182 \\
182 \\
182 \\
182 \\
182 \\
182 \\
182 \\
182 \\
182 \\
182 \\
182 \\
182 \\
182 \\
182 \\
182 \\
182 \\
182 \\
182 \\
182 \\
182 \\
182 \\
182 \\
182 \\
182\end{array}$ & $\begin{array}{l}4: 1 \\
4: 1 \\
4: 1 \\
4: 1 \\
4: 0 \\
4: 0 \\
3: 9 \\
3: 9 \\
3: 8 \\
3: 8 \\
3: 8 \\
3: 8 \\
3: 7 \\
3: 7 \\
3: 7 \\
3: 7 \\
3: 6 \\
3: 5 \\
3: 5 \\
3: 5 \\
3: 5 \\
3: 3 \\
3: 3 \\
3: 3 \\
3: 3 \\
3: 2 \\
3: 2 \\
3: 1 \\
3 \\
3: 1 \\
2: 8\end{array}$ & $\begin{array}{l}4: 16 \\
4: 15 \\
4: 11 \\
4: 09 \\
4: 05 \\
4: 03 \\
3: 94 \\
3: 89 \\
3: 87 \\
3: 81 \\
3: 80 \\
3: 79 \\
3: 77 \\
3: 71 \\
3: 69 \\
3: 62 \\
3: 59 \\
3: 53 \\
3: 50 \\
3: 50 \\
3: 43 \\
3: 30 \\
3: 28 \\
3: 28 \\
3: 26 \\
3: 25 \\
3: 15 \\
3: 13 \\
3: 11 \\
2: 84\end{array}$ & $\begin{array}{l}1: 31 \\
1: 30 \\
1: 24 \\
1: 20 \\
1: 15 \\
1: 11 \\
: 99 \\
: 93 \\
: 90 \\
: 80 \\
: 79 \\
: 775 \\
: 69 \\
: 67 \\
: 58 \\
: 55 \\
: 48 \\
: 45 \\
: 45 \\
: 38 \\
: 27 \\
: 21 \\
: 21 \\
: 20 \\
: 19 \\
: 08 \\
: 07 \\
: 05 \\
-22\end{array}$ & $\begin{array}{l}109 \\
009 \\
009 \\
009 \\
009 \\
009 \\
009 \\
009 \\
008 \\
008 \\
008 \\
008 \\
008 \\
008 \\
008 \\
080 \\
008 \\
008 \\
008 \\
008 \\
088 \\
008 \\
008 \\
008 \\
008 \\
008 \\
008 \\
008 \\
008 \\
008 \\
008 \\
: 07 \\
007\end{array}$ & 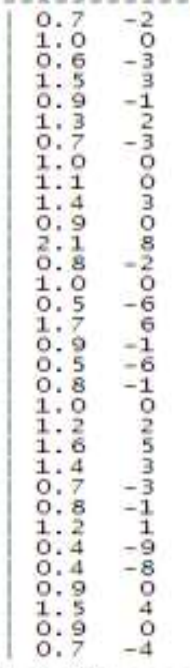 & $\begin{array}{rr}0.8 & -2 \\
1: 0 & 0 \\
0: 6 & -3 \\
1: 6 & 4 \\
0: 9 & -1 \\
1: 3 & 2 \\
0: 7 & -2 \\
1: 0 & 0 \\
1: 1 & 0 \\
1: 4 & 3 \\
1: 0 & 0 \\
2: 2 & 8 \\
0: 8 & -2 \\
1: 0 & 0 \\
01: 5 & -6 \\
1: 7 & 5 \\
0: 9 & -1 \\
0: 5 & -5 \\
0: 8 & -1 \\
1: 1 & 0 \\
1: 3 & 2 \\
1: 6 & 5 \\
1: 4 & 3 \\
0: 7 & -3 \\
0: 9 & -1 \\
1: 2 & 2 \\
0: 4 & -8 \\
0: 4 & -8 \\
0: 9 & 0 \\
1: 5 & 4 \\
0: 9 & 0 \\
0: 7 & -4\end{array}$ & $\begin{array}{rr}9 & 39 \\
12 & 312 \\
19 & 319 \\
4 & 34 \\
8 & 38 \\
14 & 314 \\
3 & 33 \\
26 & 326 \\
25 & 325 \\
16 & 316 \\
29 & 329 \\
20 & 320 \\
31 & 331 \\
27 & 327 \\
1 & 31 \\
2 & 32 \\
15 & 315 \\
17 & 317 \\
23 & 323 \\
6 & 36 \\
22 & 322 \\
13 & 313 \\
30 & 330 \\
32 & 332 \\
10 & 310 \\
18 & 318 \\
21 & 321 \\
24 & 324 \\
5 & 35 \\
28 & 328 \\
11 & 3711 \\
11 & 311\end{array}$ \\
\hline $\begin{array}{l}\text { Obsvd } \\
\text { Score }\end{array}$ & $\begin{array}{l}\text { Obsvd } \\
\text { Count }\end{array}$ & $\begin{array}{l}\text { obsvd } \\
\text { Average }\end{array}$ & $\begin{array}{l}\text { Fatr } \\
\text { Avrage }\end{array}$ & | Measure & $\begin{array}{l}\text { Mode1 } \\
\text { S.E. }\end{array}$ & $\begin{array}{l}\text { Infit } \\
\text { Mnsq zstd }\end{array}$ & $\begin{array}{l}\text { Outfit } \\
\text { Mnsq zstd }\end{array}$ & Nu Juri \\
\hline $654: 1$ & 182 & $\begin{array}{l}3.6 \\
0.3\end{array}$ & $\begin{array}{l}3.62 \\
0.35\end{array}$ & $: 61$ & $: 08$ & $\begin{array}{l}1.0 \\
0.4\end{array}$ & $\begin{array}{rr}1.0 & -0.3 \\
0.4 & 4.1\end{array}$ & $\begin{array}{l}\text { Mean (count: } 32) \\
\text { s.D. }\end{array}$ \\
\hline
\end{tabular}

Table 3 shows the information on the evaluators' comparison of generousness/rigorousness regarding the qualities of TTF textbooks. In the order from the most generous to the most rigorous according to their scores at the end of the evaluation, J9 was the evaluator who displayed the most generouswith 752 points and $\mathrm{J} 11$ was the evaluator who displayed the most rigorous behavior with 517 points. On the other hand, the evaluator separation index was 4.89 and the reliability coefficient was 0.96. A significant difference was found among the evaluators' scores in terms of generousness/rigorousness $\left(\mathrm{x}^{2}=778.8, \mathrm{sd}=31, \mathrm{p}=0.42\right)$.

Table 2 presented the infit and outfit statistical values of the facets determined in the Rasch model. When the table was investigated, some evaluators were not found in the expected quality control values (1.4-0.6). At this point, the mean squares of the evaluators' infit and outfit between the expected values indicate they exhibited consistent behaviors (Wright \& Linacre, 1994). The infit and outfit values of J4, J20, J2, J13, and J28 were not in the expected range (1.4-0.6). Similarly, the outfit value of J4 exceeded the expected range. This result revealed the 24 evaluators except the aforementioned ones displayed consistent behaviors in evaluating the qualities of TTF textbooks.

Table 3 presents the items investigated in terms of their fitness for purpose the teachers used to evaluate the relevant textbooks. The item "There are objectives on computer-aided project and research" (I6) under the heading of Objectives of the Textbook and "There are activities regarding different writing activities (controlled writing, free writing etc.)" (I18) under the heading of Effect of the Textbook on Speaking and Writing Skills and Vocabulary and Grammar Teaching were the items the teachers found the most difficult to evaluate in the textbooks. Conversely, the item "There exists a set (textbook, workbook, CD)" (I3) under the heading of Physical Characteristics of the Textbooks and "Activities are suitable for pair work and group studies" under the heading of Methods and Techniques Included in the Textbook were the items that the participants found the least difficult to evaluate. 
Table 4. Competency statistics used in the evaluation of TTF textbooks

\begin{tabular}{|c|c|c|c|c|c|c|c|c|c|c|c|}
\hline $\begin{array}{l}\text { Obsvd } \\
\text { score }\end{array}$ & $\begin{array}{l}\text { Obsvd } \\
\text { count }\end{array}$ & $\begin{array}{l}\text { Obsvd } \\
\text { Average }\end{array}$ & $\begin{array}{l}\text { Fair } \\
\text { Avrage }\end{array}$ & | measure & $\begin{array}{l}\text { Mode1 } \\
\text { S.E. }\end{array}$ & $\mid \begin{array}{c}\operatorname{Inf} \\
\operatorname{Mnsq}\end{array}$ & $\begin{array}{l}\text { t } \\
\text { zstd }\end{array}$ & $\begin{array}{l}\text { Outf } \\
\text { Mnsq }\end{array}$ & $\begin{array}{l}\text { it } \\
\text { zstd }\end{array}$ & $\mathrm{Nu}$ & Madde $1 \mathrm{er}$ \\
\hline $\begin{array}{l}709 \\
709 \\
728 \\
749 \\
750 \\
756 \\
765 \\
773 \\
774 \\
777 \\
790 \\
804 \\
807 \\
817 \\
821 \\
822 \\
823 \\
828 \\
831 \\
838 \\
848 \\
852 \\
856 \\
861 \\
871 \\
973\end{array}$ & $\begin{array}{l}224 \\
224 \\
224 \\
224 \\
224 \\
224 \\
224 \\
224 \\
224 \\
224 \\
224 \\
224 \\
224 \\
224 \\
224 \\
224 \\
224 \\
224 \\
224 \\
224 \\
224 \\
224 \\
224 \\
224 \\
224 \\
224\end{array}$ & $\begin{array}{l}3.2 \\
3.2 \\
3.3 \\
3.3 \\
3.3 \\
3.4 \\
3.4 \\
3.5 \\
3.5 \\
3.5 \\
3.5 \\
3.6 \\
3.6 \\
3.6 \\
3.7 \\
3.7 \\
3.7 \\
3.7 \\
3.7 \\
3.7 \\
3.8 \\
3.8 \\
3.8 \\
3.8 \\
3.9 \\
4.3\end{array}$ & $\begin{array}{l}3.18 \\
3.18 \\
3.27 \\
3.37 \\
3.37 \\
3.40 \\
3.44 \\
3.48 \\
3.48 \\
3.50 \\
3.56 \\
3.62 \\
3.64 \\
3.68 \\
3.70 \\
3.70 \\
3.71 \\
3.73 \\
3.75 \\
3.78 \\
3.82 \\
3.84 \\
3.86 \\
3.88 \\
3.93 \\
4.38\end{array}$ & $\begin{array}{r}.49 \\
.49 \\
.40 \\
.30 \\
.30 \\
.27 \\
.22 \\
.18 \\
.18 \\
.16 \\
.10 \\
.02 \\
.01 \\
-.05 \\
-.07 \\
-.07 \\
-.08 \\
-.11 \\
-.12 \\
-.16 \\
-.22 \\
-.24 \\
-. .27 \\
-.29 \\
-.35 \\
-1.09\end{array}$ & $\begin{array}{l}.07 \\
.07 \\
.07 \\
.07 \\
.07 \\
.07 \\
.07 \\
.07 \\
.07 \\
.07 \\
.07 \\
.07 \\
.07 \\
.07 \\
.07 \\
.07 \\
.07 \\
.07 \\
.07 \\
.07 \\
.08 \\
.08 \\
.08 \\
.08 \\
.08 \\
.09\end{array}$ & $\begin{array}{l}1.1 \\
0.9 \\
1.0 \\
0.8 \\
1.0 \\
0.9 \\
0.8 \\
0.8 \\
1.0 \\
0.8 \\
1.4 \\
0.7 \\
1.3 \\
1.0 \\
1.1 \\
0.9 \\
1.0 \\
1.1 \\
1.0 \\
0.9 \\
0.9 \\
0.9 \\
1.1 \\
0.9 \\
1.2 \\
2.0\end{array}$ & $\begin{array}{r}1 \\
-1 \\
0 \\
-2 \\
0 \\
-1 \\
-2 \\
-2 \\
0 \\
-2 \\
3 \\
-3 \\
3 \\
0 \\
0 \\
-1 \\
0 \\
1 \\
0 \\
0 \\
-1 \\
0 \\
1 \\
0 \\
2 \\
7\end{array}$ & $\begin{array}{l}1.1 \\
0.9 \\
1.0 \\
0.8 \\
1.0 \\
0.9 \\
0.8 \\
0.8 \\
1.0 \\
0.8 \\
1.3 \\
0.8 \\
1.3 \\
1.0 \\
1.1 \\
0.9 \\
1.1 \\
1.1 \\
1.0 \\
0.9 \\
0.9 \\
0.9 \\
1.1 \\
0.9 \\
1.2 \\
1.8\end{array}$ & $\begin{array}{r}1 \\
0 \\
0 \\
-2 \\
0 \\
-1 \\
-2 \\
-2 \\
0 \\
-2 \\
3 \\
-3 \\
2 \\
0 \\
1 \\
-1 \\
0 \\
1 \\
0 \\
0 \\
-1 \\
0 \\
1 \\
0 \\
1 \\
6\end{array}$ & $\begin{array}{r}6 \\
19 \\
20 \\
11 \\
16 \\
10 \\
21 \\
17 \\
18 \\
22 \\
1 \\
14 \\
13 \\
4 \\
2 \\
23 \\
12 \\
25 \\
9 \\
26 \\
15 \\
7 \\
5 \\
8 \\
24 \\
3\end{array}$ & $\begin{array}{l}\text { M1 } \\
M 19 \\
M 20 \\
M 11 \\
M 16 \\
M 10 \\
M 21 \\
M 17 \\
M 18 \\
M 22 \\
M 1 \\
M 14 \\
M 13 \\
M 4 \\
M 2 \\
M 23 \\
M 12 \\
M 25 \\
M 9 \\
M 26 \\
M 15 \\
M 7 \\
M 5 \\
M 8 \\
M 24 \\
M 3\end{array}$ \\
\hline $\begin{array}{l}\text { Obsvd } \\
\text { Score }\end{array}$ & $\begin{array}{l}\text { Obsvd } \\
\text { count }\end{array}$ & $\begin{array}{l}\text { Obsvd } \\
\text { Average }\end{array}$ & $\begin{array}{c}\text { Fair } \\
\text { Avrage }\end{array}$ & | measure & $\begin{array}{l}\text { Mode1 } \\
\text { S.E. }\end{array}$ & $\mid \begin{array}{c}\text { Infi } \\
\text { Mnsq }\end{array}$ & $\begin{array}{l}\text { t } \\
\text { zstd }\end{array}$ & $\begin{array}{l}\text { Outf } \\
\text { Mnsq }\end{array}$ & $\begin{array}{l}\text { it } \\
\text { zstd }\end{array}$ & & Maddeler \\
\hline $\begin{array}{r}805.1 \\
56.6\end{array}$ & $\begin{array}{r}224 \\
0\end{array}$ & $\begin{array}{l}3.6 \\
0.3\end{array}$ & $\begin{array}{l}3.63 \\
0.26\end{array}$ & $\begin{array}{l}.00 \\
.32\end{array}$ & $\begin{array}{l}.07 \\
.00\end{array}$ & $\begin{array}{l}1.0 \\
0.3\end{array}$ & $\begin{array}{r}-0.1 \\
2.3\end{array}$ & $\begin{array}{l}1.0 \\
0.2\end{array}$ & $\begin{array}{l}0.0 \\
2.1\end{array}$ & $\begin{array}{l}\text { Mea } \\
\text { S. D }\end{array}$ & an (count: 26) \\
\hline $\begin{array}{l}\text { MSE (Mod } \\
\text { ixed (a) } \\
\text { andom (n }\end{array}$ & $\begin{array}{l}\text { 1) } \\
1 \text { same } \\
\text { orma } 1 \text { ) }\end{array}$ & {$\left[\begin{array}{c}07 \text { Adj } \\
\text { chi-squ } \\
\text { chi-squa }\end{array}\right.$} & $\begin{array}{l}\text { 5.D. } \\
\text { uare: } 4 \\
\text { are: } 24\end{array}$ & $\begin{array}{ll}31 & \text { sep } \\
5.3 & \text { d. } \\
\text { d.f. }\end{array}$ & $\begin{array}{l}\text { parat i } \\
f::_{24} 25 \\
: 24\end{array}$ & $\begin{array}{l}4.2 \\
\text { igni } \\
\text { gnif }\end{array}$ & $\begin{array}{l}5 \text { Re } \\
\text { ficand } \\
\text { cance }\end{array}$ & $\begin{array}{l}\text { liabi } \\
\text { ce: } \\
: .4 \dot{2}\end{array}$ & & 95 & \\
\hline
\end{tabular}

The items used in the evaluation of TTF textbooks were analyzed and the RMSE value was found to be 0.07 . This value indicates that the standard error associated with determining the quality is very low. Considering the relevant error value, the adjusted standard deviation value (Adj. S.D.) was below the critical value of $1.0(0.31)$. Furthermore, the reliability coefficient of the items used to determine the qualities of the textbooks was calculated and a value of 0.95 was reached. This value reflected that the items were highly reliable in evaluating the textbooks.

As Table 4 shows, the separation index was 4.25 ; whereas the reliability was 0.95 . In this case, the items used to reveal the qualities of the textbooks were significant in terms their difficulties $(\chi 2=425.3$ $\mathrm{sd}=24, \mathrm{p}=0.42$ ). When the infit and outfit statistical values of the facets were evaluated, only I3 exceeded the boundary values determined for the outfit index. This result showed that all other items are within the limit values and are acceptable. In other words, the mean squares of infit and outfit values of all other items except the aforementioned item were within the expected values. 
Table 5. Interaction analysis of the evaluators and the TTF textbooks evaluated

\begin{tabular}{|c|c|c|c|c|c|c|c|c|c|c|c|c|c|c|c|c|}
\hline $\begin{array}{l}\text { obsvd } \\
\text { score }\end{array}$ & $\begin{array}{l}\text { Exp. } \\
\text { score }\end{array}$ & $\begin{array}{l}\text { Obsvd } \\
\text { count }\end{array}$ & $\begin{array}{l}\text { Obs-Exp } \\
\text { Aver age }\end{array}$ & $\begin{array}{l}\text { Biast } \\
\text { Measure }\end{array}$ & $\begin{array}{l}\text { Model } \\
\text { S.E. }\end{array}$ & $z$-score & $\begin{array}{l}\text { Infit } \\
\text { Nnsq }\end{array}$ & $\begin{array}{c}\text { Outfit } \\
\text { Nnsq }\end{array}$ & $5 q$ & $\mathrm{~N}$ & TOWEF & & measr & Nu & Jür i & measr \\
\hline $\begin{array}{l}53 \\
55 \\
58 \\
51 \\
54 \\
85 \\
85 \\
82 \\
61 \\
62 \\
54 \\
64 \\
54\end{array}$ & $\begin{array}{r}100.9 \\
101.3 \\
90.9 \\
81.1 \\
79.8 \\
103.8 \\
103.5 \\
100.8 \\
82.4 \\
82.6 \\
75.0 \\
84.2 \\
74.7\end{array}$ & $\begin{array}{l}26 \\
26 \\
26 \\
26 \\
26 \\
26 \\
26 \\
26 \\
26 \\
26 \\
26 \\
26 \\
26\end{array}$ & $\begin{array}{l}-1.84 \\
-1.78 \\
-1.27 \\
-1.16 \\
-.99 \\
-.72 \\
-.71 \\
-.72 \\
-.82 \\
-.79 \\
-.81 \\
-.78 \\
-.80\end{array}$ & $\begin{array}{l}2.01 \\
1.93 \\
1.32 \\
1.24 \\
1.04 \\
.87 \\
.85 \\
.83 \\
.84 \\
.81 \\
.86 \\
.79 \\
.85\end{array}$ & $\begin{array}{l}.22 \\
.21 \\
.21 \\
.22 \\
.22 \\
.20 \\
.20 \\
.20 \\
.20 \\
.20 \\
.22 \\
.20 \\
.22\end{array}$ & $\begin{array}{l}9.23 \\
9.08 \\
6.35 \\
5.56 \\
4.84 \\
4.30 \\
4.21 \\
4.15 \\
4.12 \\
4.00 \\
3.98 \\
3.94 \\
3.93\end{array}$ & $\begin{array}{l}0.6 \\
0.6 \\
0.9 \\
1.2 \\
1.5 \\
0.7 \\
0.7 \\
0.2 \\
1.4 \\
1.5 \\
0.5 \\
0.9 \\
0.5\end{array}$ & $\begin{array}{l}0.6 \\
0.6 \\
0.9 \\
1.2 \\
1.4 \\
0.7 \\
0.7 \\
0.2 \\
1.4 \\
1.5 \\
0.5 \\
0.9 \\
0.5\end{array}$ & $\begin{array}{r}139 \\
140 \\
120 \\
87 \\
207 \\
182 \\
181 \\
129 \\
89 \\
88 \\
32 \\
40 \\
33\end{array}$ & $\begin{array}{l}6 \\
7 \\
1 \\
3 \\
4 \\
7 \\
6 \\
3 \\
5 \\
4 \\
4 \\
5 \\
5\end{array}$ & $\begin{array}{l}\text { YA1 } \\
\text { YA2 } \\
\text { IA1 } \\
\text { HA1 } \\
\text { GA1 } \\
\text { YA2 } \\
\text { YA1 } \\
\text { HA1 } \\
\text { GA2 } \\
\text { GA1 } \\
\text { GA1 } \\
\text { GA2 } \\
\text { GA2 }\end{array}$ & $\begin{array}{l}6 \\
7 \\
1 \\
3 \\
4 \\
7 \\
6 \\
3 \\
5 \\
4 \\
4 \\
5 \\
5\end{array}$ & $\begin{array}{r}.14 \\
.16 \\
.25 \\
-.32 \\
-.26 \\
.16 \\
.14 \\
-.32 \\
-.27 \\
-.26 \\
-.26 \\
=.27 \\
=.27\end{array}$ & $\begin{array}{l}20 \\
20 \\
18 \\
13 \\
30 \\
26 \\
26 \\
19 \\
13 \\
13 \\
5 \\
6 \\
5\end{array}$ & $\begin{array}{l}320 \\
320 \\
318 \\
313 \\
330 \\
326 \\
326 \\
319 \\
313 \\
313 \\
35 \\
36 \\
35\end{array}$ & $\begin{array}{r}.79 \\
.79 \\
.21 \\
.38 \\
.27 \\
.93 \\
.93 \\
1.24 \\
.38 \\
.38 \\
.08 \\
.45 \\
.08\end{array}$ \\
\hline $\begin{array}{r}111 \\
109 \\
98 \\
109 \\
98 \\
113 \\
117 \\
113 \\
113 \\
110 \\
126 \\
114 \\
114 \\
112 \\
114\end{array}$ & $\begin{array}{r}92.5 \\
89.9 \\
77.9 \\
89.5 \\
77.5 \\
92.6 \\
97.0 \\
92.5 \\
91.9 \\
88.3 \\
103.7 \\
92.2 \\
91.2 \\
88.7 \\
86.2\end{array}$ & $\begin{array}{l}26 \\
26 \\
26 \\
26 \\
26 \\
26 \\
26 \\
26 \\
26 \\
26 \\
26 \\
26 \\
26 \\
26 \\
26\end{array}$ & $\begin{array}{r}.71 \\
.73 \\
.77 \\
.75 \\
.79 \\
.79 \\
.77 \\
.79 \\
.81 \\
.84 \\
.86 \\
.84 \\
.88 \\
.90 \\
1.07\end{array}$ & $\begin{array}{r}-.99 \\
-.97 \\
-.85 \\
-.99 \\
-.87 \\
-1.13 \\
-1.26 \\
-1.14 \\
-1.16 \\
-1.10 \\
-2.25 \\
-1.23 \\
-1.27 \\
-1.22 \\
-1.48\end{array}$ & $\begin{array}{l}.26 \\
.25 \\
.22 \\
.25 \\
.22 \\
.27 \\
.31 \\
.27 \\
.27 \\
.26 \\
.52 \\
.28 \\
.28 \\
.27 \\
.28\end{array}$ & $\begin{array}{l}-3.76 \\
-3.82 \\
-3.86 \\
-3.89 \\
-3.94 \\
-4.12 \\
-4.14 \\
-4.14 \\
-4.23 \\
-4.28 \\
-4.36 \\
-4.37 \\
-4.52 \\
-4.56 \\
-5.25\end{array}$ & $\begin{array}{l}0.6 \\
1.1 \\
0.4 \\
0.9 \\
0.4 \\
0.7 \\
1.0 \\
2.1 \\
1.7 \\
0.9 \\
0.8 \\
0.8 \\
1.0 \\
1.1 \\
1.2\end{array}$ & $\begin{array}{l}0.7 \\
1.2 \\
0.4 \\
1.0 \\
0.4 \\
0.7 \\
1.0 \\
3.4 \\
2.4 \\
0.9 \\
0.8 \\
0.8 \\
1.0 \\
1.2 \\
1.1\end{array}$ & $\begin{array}{r}137 \\
210 \\
77 \\
209 \\
76 \\
91 \\
37 \\
201 \\
214 \\
125 \\
135 \\
90 \\
136 \\
126 \\
101\end{array}$ & $\begin{array}{l}4 \\
7 \\
7 \\
6 \\
6 \\
7 \\
2 \\
5 \\
4 \\
6 \\
2 \\
6 \\
3 \\
7 \\
3\end{array}$ & $\begin{array}{l}\text { GA1 } \\
\text { YA2 } \\
\text { YA2 } \\
\text { YA1 } \\
\text { YA1 } \\
\text { YA2 } \\
\text { IA2 } \\
\text { GA2 } \\
\text { GA1 } \\
\text { YA1 } \\
\text { IA2 } \\
\text { YA1 } \\
\text { HA1 } \\
\text { YA2 } \\
\text { MA1 }\end{array}$ & $\begin{array}{l}4 \\
7 \\
7 \\
6 \\
6 \\
7 \\
2 \\
5 \\
4 \\
6 \\
2 \\
6 \\
3 \\
7 \\
3\end{array}$ & $\begin{array}{r}-.26 \\
.16 \\
.16 \\
.14 \\
.14 \\
.16 \\
.29 \\
-.27 \\
-.26 \\
.14 \\
.29 \\
.14 \\
-.32 \\
.16 \\
-.32\end{array}$ & $\begin{array}{l}20 \\
30 \\
11 \\
30 \\
11 \\
13 \\
6 \\
29 \\
31 \\
18 \\
20 \\
13 \\
20 \\
18 \\
15\end{array}$ & $\begin{array}{l}320 \\
j 30 \\
311 \\
j 30 \\
311 \\
j 13 \\
36 \\
j 29 \\
j 31 \\
318 \\
320 \\
313 \\
320 \\
j 18 \\
315\end{array}$ & $\begin{array}{r}.79 \\
.27 \\
: .22 \\
.27 \\
: .22 \\
.38 \\
.45 \\
.80 \\
.76 \\
.21 \\
.79 \\
.38 \\
.79 \\
.21 \\
.58\end{array}$ \\
\hline $\begin{array}{l}\text { bsvd } \\
\text { core }\end{array}$ & $\begin{array}{l}\text { Exp. } \\
\text { Score }\end{array}$ & $\begin{array}{l}\text { Obsvid } \\
\text { coune }\end{array}$ & $\begin{array}{l}\text { obs-Exp } \\
\text { Average }\end{array}$ & $\begin{array}{l}\text { Biast } \\
\text { Measure }\end{array}$ & $\begin{array}{c}\text { Model } \\
5 . \mathrm{E} .\end{array}$ & $z$-score & $\mid \begin{array}{r}\text { Infit } \\
\text { Mnsa }\end{array}$ & $\underset{\text { Outfit }}{\text { Onsq }}$ & $5 q$ & & & & measr & $\mathrm{Nu}$ & Jur $i$ & measr \\
\hline $\begin{array}{l}93.4 \\
15.7\end{array}$ & $\begin{array}{l}93.4 \\
10.4\end{array}$ & $\begin{array}{r}26 . \\
0 .\end{array}$ & $\begin{array}{l}.00 \\
.45\end{array}$ & $\begin{array}{r}.04 \\
.57\end{array}$ & $\begin{array}{l}.23 \\
.04\end{array}$ & $\begin{array}{r}.00 \\
2.35\end{array}$ & $\begin{array}{l}0.8 \\
0.8\end{array}$ & $\begin{array}{l}0.5 \\
0.5\end{array}$ & $\begin{array}{l}\text { Mear } \\
\text { S. D. }\end{array}$ & & (coun & & 224) & & & \\
\hline
\end{tabular}

Table 5 presented the interaction analysis of the TTF textbooks conducted by the evaluators. An interaction bias can be stated where a value is found out of the -2 and +2 range (Semerci, 2011). It is striking that the $\mathrm{Z}$ scores calculated in Table 4 are between -5.25 and 9.23. When the bias analysis was made for these values, it was determined the Evaluators displayed quite rigorous or generous behaviors in the evaluation of textbooks. This situation can be clarified by stating the result that $\mathrm{J} 20$ gave 53 points to YA1 textbook instead of 100 points $(Z=9.08)$. Similarly, the same evaluator exhibited a rigorous behavior by giving 55 points to YA2 textbook instead of approximately 101 points. On the quite contrary, J15 displayed a generous behavior by giving 114 points to HA1 textbook instead of 86 points $(Z=-5.25)$. Therefore, the evaluators demonstrated unbiased scoring.

\subsection{Qualitative results on the TTF book sets}

The Turkish lecturers' perspectives of the book sets used to teach Turkish to Foreigners were categorized under particular themes and models. The participants were asked to evaluate each book set from different points of view and four different models were created. In these models, books were investigated which best reflect the objectives of Turkish Education for Foreigners (TEF). Suggestions were made to compare books and the distribution of language skills as well as the appropriateness of the book content to students' levels.

As Figure 1 illustrates, each book possessed different characteristics in terms of the best fulfillment of the TEF objectives. The book set titled "Istanbul" included evaluations such as "writing topics are very good, the content reflects the objectives, the objectives are appropriate to the Criteria of Common European Framework of Reference for Languages, it is annually updated based on users' feedback, different assessment questions at the end of units are included, grammar topics are presented in a clear, simple and understandable way, and the texts are contemporary. Some of the participants' perspectives 
were as follows: "I think that Istanbul books reflect the content and objectives well. We can say that the explanation of suffixes in the grammar section is not understandable to students. For example, the suffixes "lar and ler" are only given in the "-LAR" form. This is not understandable for the students. Consequently, the teacher must clarify this grammar point. This illustrates only one example in the grammar sections. Reading, listening texts, writing topics followed the STS format." (P12m), "I think that Istanbul-TOMER is the book that best reflects the objectives of teaching Turkish to foreigners. It was well designed for both the teacher and the student in terms of grammar. Considering the other objectives (reading-writing-listening), the book was enriched by both visuals and different activities" (P33f).

The Yeni Hitit book showed evaluations such as "plenty of examples and explanations are included, the objectives are reflected well, a systematic presentation of the objectives is included, it has an intense content to meet the objectives, "intense activities are useful, objective-based activities are included, listening activities are qualified, and a detailed presentation is provided. These illustrations were derived from these viewpoints of the participants: "I think that Hitit best reflects the objectives because an intense activity program exists in the book to reach the objectives. Students have intense activities throughout the book. This facilitates students meeting the objective." (P8m) "I think that Hitit books reflect the content and objectives well... There are many examples and explanations in Hitit book... the objectives are reflected in an extremely good way." (P12m). In the Gazi book in Figure 2, the evaluations "objectives at every level language level are included" and "different paths of presentation are included" were noteworthy. The perspective "the teacher's burden is high in the Gazi book. Only a very good teacher can use the Gazi book. However, it included exercises with different content making the book meaningful" was encouraging. 


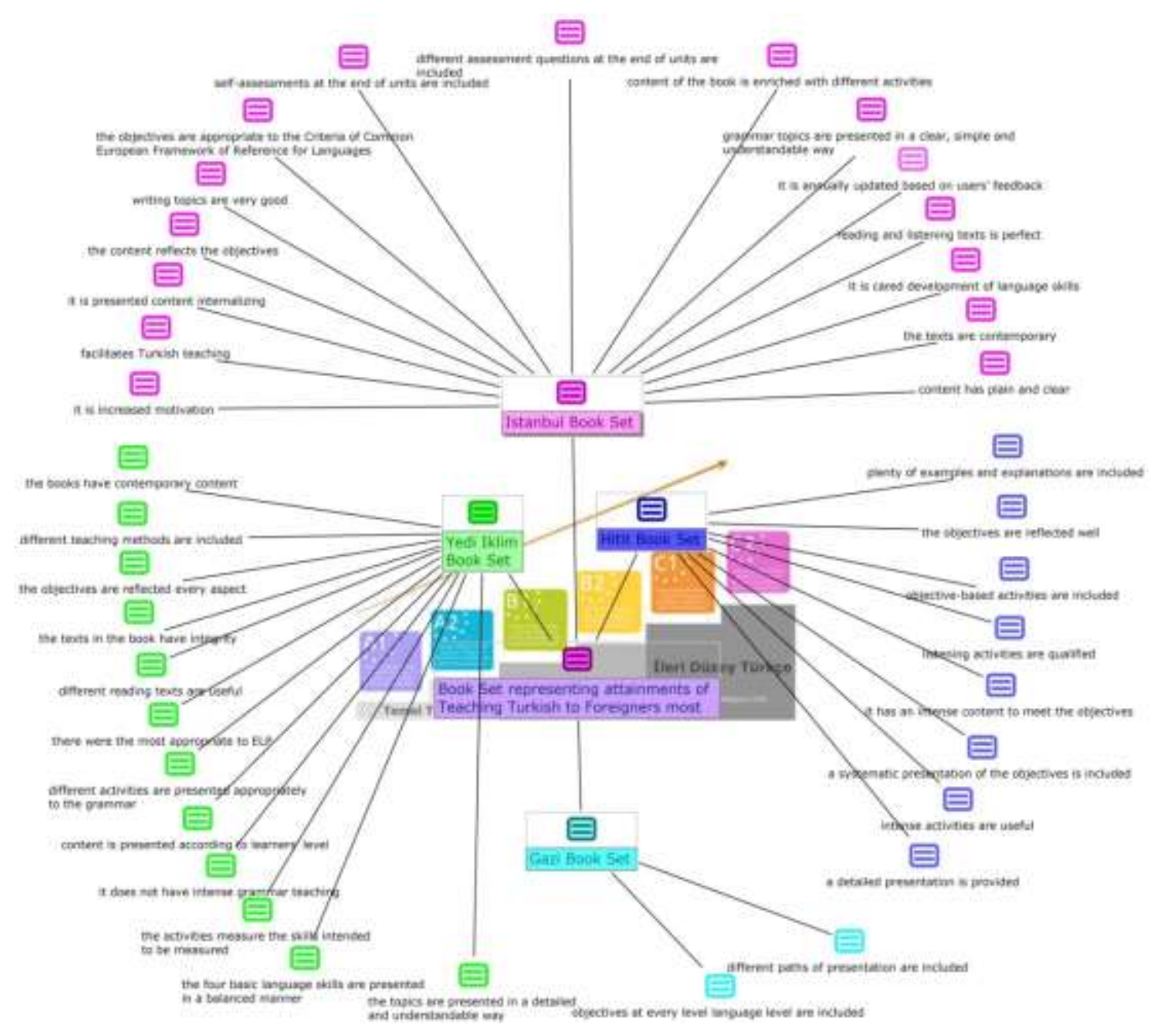

Figure 1.Book set that best reflects TEF objectives

Figure 1 presents the codes of the perspectives on how the Yedi İklim book set reflected the level of TEF objectives. When these codes were investigated, the Yedi İklim book set was found to possess characteristics such as "the books have contemporary content, the activities measure the skills intended to be measured, different activities are presented appropriately to the grammar, the four basic language skills are presented in a balanced manner, the topics are presented in a detailed and understandable way, the texts in the book have integrity, and it does not have intense grammar teaching. Some of the excerpts from the participants' perspectives on this issue are: the Yedilklim book sets best reflect the objectives since they are the most updated" (P3f); "I think it is Yediİklim. It, along with the activities, measures skills intended to be measured. The reading speed of the listening texts is appropriate. Different activities are presented appropriately to the grammar. However, the level of texts is mostly higher than the level" (P7f); and "Yedi İklim comes to the forefront in terms of text and voiceover" (P34m).

Figure 2 presented the suggestions made in terms of improving the book sets used in TEF to achieve the program objectives. The participants proposed the following to improve the İstanbul book set: "it should include more of the activities that improve writing and speaking skills, current errors in the book should be corrected, the topic distribution of units should be consistent with the grammar rules, writing and speaking activities should not repeat themselves, questions in the listening texts should not assess the writing skills, and simple and template sentences in the book should be changed. Some of these codes were formed considering the perspective that "Language skills are prepared in the books prioritizing reading and grammar. Many writing and speaking topics repeat themselves in the book. 
They are not presented in a way motivating students to speak or write. They cause the feeling that grammar and reading are much more important and students should focus more on these skills." identified by $\mathbf{P 1 2} \mathbf{m}$.

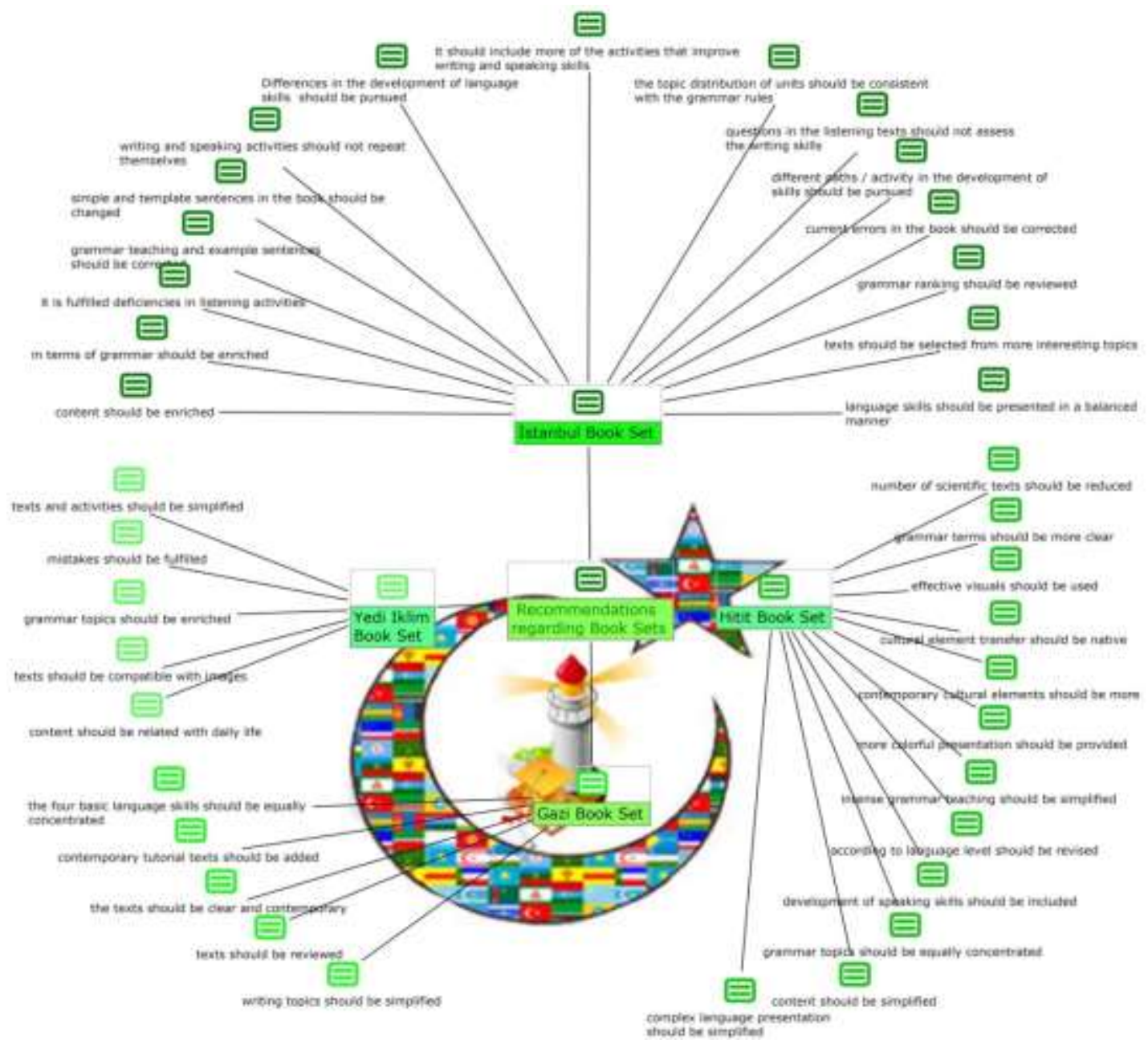

Figure 2.Suggestions for TEF book types

In Figure 2, suggestions based on the intense content and grammar-based characteristics of Yeni Hitit book set were also noted. Some of these suggestions were: "content should be simplified, grammar topics should be prepared according to learners' level, the intense grammar teaching should be simplified, and complex language presentation should be simplified, which particularly underline the intensity of the book. On this issue, P19f suggested that "Grammar topics in Hitit book are sometimes higher than the level of the learners. In particular, the presence of compound tense on the level A challenges students. Grammar terms are also not commonly or frequently used." Again, P2f suggested that "Hitit book has a quite intensive grammar focus. The content should be simplified" while highlighting the intensity of the grammar. Although the suggestions made for Gazi book were similar to the ones for the Yeni Hitit book, different suggestions such as the four basic language skills should be equally concentrated, the texts should be clear and contemporary, writing topics should be simplified, and texts should be reviewed were also presented. The perspective that "it was seen that the four basic skills were not equally concentrated in the Gazi book and that reading included more" (P19f) was taken as a reference to form the codes. Lastly, the codes "grammar topics should be enriched, content should be related with daily life, and texts and activities should be simplified" were suggestions made to improve the Yedi İklim book set. The simplification of the books was particularly emphasized by the 
participants. One of the participants' perspectives on the Yediliklim book set was: “...the Yedi İklim book set contains many mistakes in every respect. such as the inconsistency of the text and pictures. Misspelling in the book can be tolerated by attributing them to typographical errors; however, the mistakes in information mislead the lecturer as well. The absence of an internal consistency is another problem of this book. While animal drawings for children constitute one page, the gate of Istanbul University and an academic text appear on the other. Topics in Yedi Iklim are unrequited in daily life..."

(P19f).

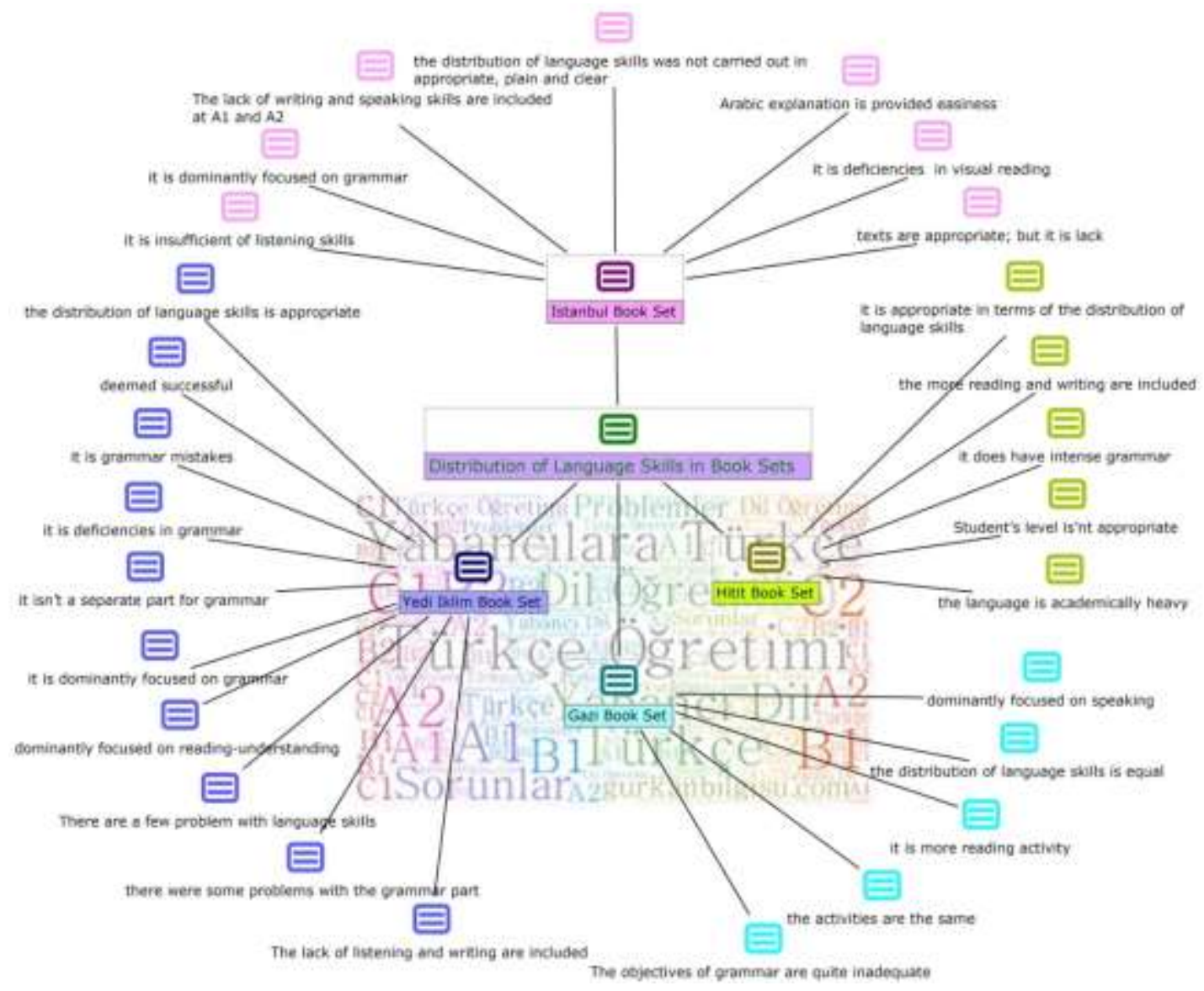

Figure 3.Perspectives on the distribution of language skills in the book sets

Figure 3 shows codes for the distribution of language skills in the book sets to teach Turkish to foreigners. In the model where separate codes are available for each book set, it was indicated for the İstanbul book set that "the distribution of language skills was not carried out in a balanced way, it is dominantly focused on grammar; listening and speaking skills are not sufficiently stated, and deficiencies are noted in visual reading." Some of the participants' perspectives on this issue were: "writing and speaking skills are not sufficiently included in Istanbul A1 and A2, more emphasis should be put on these skills. For this reason, teachers need to make an extra effort" (P9f) and "I think that Istanbul book is quite insufficient in terms of visual reading skills" (P8m). The codes such as "it is appropriate in terms of the distribution of language skills; however, the language is academically heavy" were striking forYeniHitit book set. The perspective that "the Hititset can be difficult according to the level since it also aims to teach the academic language. While the distribution of the skills is appropriate, grammar teaching is overly intense" (P22m) was referenced in forming these codes. In the Gazi book set, the codes such as "the distribution of language skills is not equal, the activities are the same" indicates that the distribution is not balanced. Lastly, some of the codes regarding the Yediliklim book 
set were "the distribution of language skills is appropriate; however, there were some problems with the grammar part but it is deemed successful." One of the perspectives from which these codes were derived was "the distribution of language skills is positive in the general sense; however, it is understood in the process that listening and writing are included less." (P22m). When all the relevant codes were considered, it can be asserted that the perspectives on the Yedi İklim book set are more positive and this was the set where the grammar distribution was carried out in the most balanced way.

\section{Discussion, Conclusion and Recommendations}

In this study, the lecturers' perspectives on textbooks used within the scope of TTF were investigated using Rasch and Maxqda analyses. The results ascertained were remarkable. Different methods were used in the study including both the Rasch analysis and the participants' perspectives in the qualitative approach. Both analyses supported and provided each other with the results. When the Rasch analysis results were investigated, it was determined among TTF textbooks that IA1 and IA2 have the highest quality and HA1 has the lowest quality. The ranking of the other books in terms of quality was IA2, IA1, YA2, YA1, GA1, GA2, and HA1. This result stems from the fact that IA1 and IA2 were attentive and meticulous in the level of reflecting the objectives, appropriateness to the students, and the distribution of language skills. In addition, the reliability coefficient was found to be 0.98 in determining the qualities of the textbooks. This value indicated that the ranking of the textbooks is reliable.

The rigorousness and generousness comparison was investigated according to the evaluation of the evaluators who expressed their perspectives of the TTF textbooks. The results revealed that J9 is the evaluator who gave the highest score and $\mathrm{J} 11$ is the one who gave the lowest score. Therefore, J9 was placed at the top of the most generous evaluator ranking and J11 was placed at the top of the most rigorous evaluator ranking. It was also noteworthy that the reliability level of the evaluators' scoring is at a high level (0.96). In terms of the infit values determined in the Rasch analysis, some evaluators were not between these values. The infit and outfit indices determined by Wright and Linacre (1994) are known as particular quality control values and are in the range of $1.4-0.6$. The indices in this range indicate consistency. Therefore, infit indices values of some evaluators infer that they do not display consistent behaviors. However, the evaluators' outfit values were between the expected values; therefore, it can be stated that they performed in a consistent manner.

Considering the difficulties of the items used to evaluate TTF textbooks, the most difficult item was I6 and the least difficult item was I3. A reliability coefficient of .95 for the items shows that these items are appropriate to determine the quality of the textbooks and are accurate measurement criteria. The fit indices of the items were also investigated. According to these indices, there was only one item that exceeded the control values determined in terms of both indices, which indicates that the consistency level of the items is at a high level. Another result reached in the Rasch analysis results is that the evaluators performed with bias. The relevant results revealed that $\mathbf{J} 20$ performed with bias in favor of generousness and that $\mathrm{J} 15$ performed with bias in favor of rigorousness.

The participants' perspectives were consulted in the qualitative dimension to contribute to the Rasch analysis results and to obtain results on TTF textbooks from a different point of view. The qualitative data obtained were presented in Maxqda models. Using the data in both dimensions together contributes to the reliability and data enrichment of the study within the scope of multiple analyses (Bamberger, 2012). When the relevant Maxqda results were investigated, it was seen that results supporting the Rasch results were obtained. In this respect, considering the participants' perspectives on the book set which best reflects the objectives, different positive perspectives were encountered for each book set. However, there were more positive perspectives about the İstanbul and Yediİklim textbooks. The results indicating 
that these textbooks reflect the objectives and they are more comprehensive in terms of involving activities on the language skills and different assessment and teaching methods were obtained. In particular, the interpretations about the İstanbul book such as "it presents the topics in a clear way, facilitates Turkish teaching, and is updated regularly" means that this book set is considered more in the foreground compared to the other books sets. The fact that the participants made fewer positive interpretations about the Gazi and YeniHitit books can indicate that these books do not have the desired quality. According to Ömeroğlu (2016), the aim of the unit and the targeted objectives are presented at the beginning of each unit in the İstanbul set. While this feature was partially organized in the Yediliklim book, the Gazi and Yeni Hitit books do not have such an organization. Ömeroğlu (2016) identified that the İstanbul and Yedi İklim books are appropriate to the objectives determined by ELP. These results were corroborated by the Rasch analysis result indicating that İstanbul (I1) is the most qualified book and Yeni Hitit is the least qualified book. Obtaining similar results influences the reliability and strength of the study results.

Suggestions that can be proposed to make TTF books more effective and qualified is another point investigated within the qualitative part of the study. Suggestions, in particular, were made about the YeniHitit book asserting that it is not sufficient. Some remedial suggestions were made on the deficiencies, including: intense grammar use, content not appropriate to the students' levels, unequal distribution of language skills and insufficient transfer of culture. According to Şimşek (2011), texts including universal cultural elements should be prominent in studies. Elements of Turkish culture and information and presentation related to Turkish history were scarcely included. References to Turkish literature and culture should be included more in the text in Yeni Hitit books, as Karababa and Üstünsoy Taşkın (2012) point out. These results again mean that the participants find the Yeni Hitit book insufficient (or less qualified); therefore, they are consistent with the least qualified textbook result of the Rasch analysis. Kılınç and Yenen (2015), according to their data, stated that the language and expression of textbooks used to teach Turkish to foreigners were not appropriate to the student level. The suggestion was to put more emphasis on listening and writing skills, which is also encountered in other books. The unequal distribution of language skills is a prominent suggestion to be highlighted. One can argue that the distribution of language skills, which was a general problem encountered in all of the books investigated, is somehow related to the lecturers' performance of these skills while using the textbooks. A lecturer who creatively applies the listening texts included and meticulously carries out the speaking texts can yield more effective results.

Language teaching consists of the functional components of listening, speaking, reading and writing that are accepted as four basic skills (Demirel, 2012). In the study, the distribution of these skills in TTF sets was also investigated. In this respect, it was again found that the İstanbul and Yedi İklim textbooks have more qualified contents. The İstanbul set contains problems in terms of the distribution of language skills and it requires teachers to work harder because of the unequal distribution. It was highlighted that the Gazi and Yeni Hitit sets do not include language skills equally and focus more on grammar. Karababa and Üstünsoy Taşkın (2012) suggested reviewing the distribution of grammar topics in Yeni Hitit books considering learners' communicative purposes and to reduce the intensity of grammar teaching. Göçer (2007) stated that in Yeni Hitit sets, the questions in the grammar teaching field are three to four times as many as the questions included in other language skills. It was determined in the study that although there are minor problems in the Yedilklim set, each skill was distributed evenly. The Yedi İklim set is more appropriate and useful in terms of the distribution of skills.

In the overall conclusion of the study, it was understood that the Yediİklim and İstanbul sets are more appropriate in terms of the level of reflecting the objectives, the quality dimension of the content, and the balanced distribution of the skills. In conclusion, it was determined that different perspectives and opinions were expressed on TTF sets in this two-dimensional study. The similar and common 
perspectives were detected and general inferences were made. Similar results obtained after the investigation of TTF textbooks in two different dimensions revealed the results that several aspects of these books should be improved. Considering the number of students attempting to learn a different language and culture, the priorities such as the appropriateness of textbooks used to the student level, understandability and richness of the content, the distribution of language skills, and the level of reflecting the objectives should be taken into consideration. Furthermore, conducting the study in two different dimensions brought more comprehensive and thorough details to the study. This study was thought to provide researchers a foundation to conduct future studies using different methods.

\section{References}

Akbulut, S. \& Yayl1, D. (2015). A study on the syllabuses of a1-a2 level Turkish as a foreign language textbook. Erzincan University Journal of Social Sciences Institute, ÖS II, 35-46.

Bamberger, M. (2012). Introduction to mixed methods in impact evaluation. Impact Evaluation Notes, $3,1-38$.

Batd1, V. (2010). An assessment of teachers'opinions about the effectiveness of English coursebook used in foreign language highschools. A case of Elazlğ and Diyarbakır. (Master's thesis), Firat University, Elazı̆̆, Turkey.

Bayezit, H. \& Çubukçu, F. (2015). The use of learning strategies in English and Turkish as a foreign language coursebooks. Abant İzet Baysal University Journal of Education Faculty, 15(1), 25-47. doi: 10.17240/aibuefd.2015.15.1-5000128593

Biçer, N. \& K1lı̧, B. S. (2017). Evaluation of text books which are used for teaching Turkish to Syrian students based on teacher opinions. Journal of Mother Tongue Education, 5(4), 649-663. doi: 10.16916/aded.329809

Chambliss, M. J., \& Calfee, R. C. (1998). Textbooks for learning - nurturing children's minds. Malden: Blackwell.

Council of Europe. (2001). Common European framework of reference for languages: learning, teaching, assessment. Strasbourg: Cambridge University Press.

Cunningsworth, A. (1995). Choosing your coursebook. Oxford: Macmillan Heinemann ELT.

Çelik, Y. \& Gülcü, İ. (2016). Teachers' views about Turkish and Turkish culture textbooks used abroad. Bartin University Journal of Faculty of Education, 5(2), 287-296. doi: 10.14686/buefad.v5i2.5000183344

Davis, L. L. (1992). Instrument review: Getting the most from a panel of experts. Applied Nursing Research, 5, 194-197.

Demir, T. (2015). Material efficiency in Turkish teaching as a foreign language-coursebooks. Language Journal, 166(1), 43-52.

Demirel, Ö. (2012). Curriculum development in education, from theory to practice. Ankara: Pegem A. Publication.

Fidan, D. (2016). Grammar subjects in Turkish as a foreign language course books and teachers'learners' views. Turkish Studies, 11(14), 257-276. doi: 10.7827/TurkishStudies.9826

Fuller, G. E. (2001). How can a foreign language be learned? İstanbul: Avesta Publication. 
Göçer, A. (2007). Analysis of textbooks in measuring and evaluating used in teaching Turkish as a foreign language. Journal of Language, 137, 30-48.

Gün, M., Akkaya, A. \& Kara, Ö. T. (2014). The assessment of Turkish class books for foreigners by the instructors in Turkish teaching centers. Turkish Studies, 9(6), 1-16. doi: 10.7827/TurkishStudies.7134

Hsieh, H. F., \& Shannon, S. E. (2005). Three approaches to qualitative content analysis. Qualitative Health Research, 15(9), 1277-1288. doi: 10.1177/1049732305276687

Karababa, Z. C. \& Üstünsoy Taşkın, S. (2012). An evaluation of the course books for teaching Turkish as a foreign language based on teacher opinions. Language Journal, 157, 65-80.

Karasar, N. (2008). Scientific research methods. (23. Edition). Ankara: Nobel Publicaion.

Kılınç, H. H. \& Yenen, E. T. (2015). Lecturers' opinions regarding textbooks used in Turkish education for foreigners. International Journal of Language Academy, 3(4), 429-441. doi: 10.18033/ijla.288

Lewins, A., \& Silver, C. (2008). Using software in qualitative research. Los Angeles, CA: Sage.

Lightbown, P. M., \& Spada, N. (2006). How languages are learned. Oxford: Oxford University Press.

Ömeroğlu, E. (2016). Review of the textbooks prepared for teaching Turkish to foreigners. (PhD dissertation), Sakarya University, Sakarya, Turkey.

Özdemir, C. (2013). The importance of teaching materials in Turkish language teaching and the required qualifications of these materials. Turkish Studies, 8(1), 2049-2056. doi: 10.7827/TurkishStudies.4495

Richards, J. C. (2001). The role of textbooks in a language program. Cambridge, UK: Cambridge University Press.

Şimşek, P. (2011). A survey on reading texts and supplementary reading books for foreigners learning Turkish. (Master's thesis), Afyon Kocatepe University, Afyon, Turkey.

Tennant, A., \& Conaghan, P. G. (2007). The Rasch measurement model in rheumatology: what is it and why use it? When should it be applied, and what should one look for in a Rasch paper? Arthritis Care \& Research, 57(8), 1358-1362.

Veneziano L. \& Hooper J. (1997). A method for quantifying content validity of health-related questionnaires. American Journal of Health Behavior, 21(1), 67-70.

Viera, A. J. \& Garrett, J. M. (2005). Understanding interobserver agreement: The kappa statistic. Family Medicine, 37(5), 360-363.

Williams, D. (1983). Developing criteria for textbook evaluation. ELT Journal, 37(3), 251-255.

Wright B. D., \& Linacre J. M. (1994). Reasonable mean-square fit values. Transactions of the Rasch measurement SIG American Educational Research Association. Rasch Measurement Transaction $8(3), 370-382$.

Yıldırım, A. \& Şimşek, H. (2008). Qualitative research methods in social sciences. (7. Edition). Ankara: Seçkin Publication. 
Appendix A. Cohen Kappa Values of Themes in the Study

\begin{tabular}{|c|c|c|c|c|c|c|c|c|c|c|c|c|c|c|}
\hline & \multicolumn{4}{|c|}{$\begin{array}{l}\text { Booksets that } \\
\text { reflect TTF } \\
\text { attainments best }\end{array}$} & \multicolumn{5}{|c|}{$\begin{array}{c}\text { Recommendations } \\
\text { related to TTF book } \\
\text { sets }\end{array}$} & \multicolumn{5}{|c|}{$\begin{array}{c}\text { Distribution of } \\
\text { language skills in } \\
\text { book sets }\end{array}$} \\
\hline \multicolumn{5}{|c|}{ K2 } & \multicolumn{5}{|c|}{$\mathrm{K} 2$} & \multicolumn{5}{|c|}{$\mathrm{K} 2$} \\
\hline \multirow{4}{*}{$\bar{v}$} & & + & - & $\Sigma$ & & & + & - & $\Sigma$ & & & + & - & $\Sigma$ \\
\hline & + & 37 & 3 & 40 & $\nabla$ & + & 37 & 2 & 39 & $\underline{V}$ & + & 27 & 3 & 30 \\
\hline & - & 4 & 19 & 23 & & - & 3 & 17 & 20 & & - & 5 & 22 & 27 \\
\hline & $\Sigma$ & 41 & 22 & 63 & & $\Sigma$ & 40 & 19 & 59 & & $\Sigma$ & 32 & 25 & 57 \\
\hline \multicolumn{3}{|c|}{ Kappa:.758 } & \multicolumn{2}{|c|}{ p:.000 } & \multicolumn{3}{|c|}{ Kappa: .809 } & \multicolumn{2}{|c|}{ p:.000 } & & app & .717 & \multicolumn{2}{|c|}{ p:.000 } \\
\hline
\end{tabular}

\title{
Yabancı dil olarak Türkçe öğretiminde kullanılan ders kitaplarının Rasch ölçme modeli ve Maxqda ile incelenmesi
}

\begin{abstract}
$\ddot{O} \mathbf{z}$
Bu çalışmanın amacı yabancı dil olarak Türkçe öğretiminde kullanılan ders kitaplarını Türkçe okutmanlarının görüşlerine göre incelemektir. Bu kapsamda yabancı dil olarak Türkçe öğretiminde kullanılan ders kitapları sahip oldukları özellikler açısından değerlendirilmiş̧ir. Bu çalışma nitel ve nicel yaklaşımlardan yararlanılarak hazırlanmıştır. Nicel boyutta Rasch ölçme modeli kullanılırken nitel boyutta ise durum çalışmasından yararlanılmıştır. Veriler toplanırken Türkiye'deki üniversitelerin Türkçe öğretim merkezlerinde görev yapan 54 okutmandan görüş alınmış ve bunlardan 32'sinin verileri araştırmada kullanılmıştır. Araştırmada nicel veri toplama aracı olarak Batdı'nın (2010) geliştirdiği ders kitaplarını değerlendirme ölçeğinden yararlanılmıştır. Nitel veriler için araştırmacılar tarafından hazırlanan yarı yapılandırılmış görüşme formu kullanılmışırı. Verilerin analizinde Rasch ve içerik analizi kullanılmıştır. İçerik analizi yapılırken Maxqda programı kullanılarak kodlar ve temalar çıkarılmıştır. Katılımcıların görüşlerini desteklemek için örnek alıntılar eklenmiştir. Çalışmanın sonucunda yabancı dil olarak Türkçe öğretiminde kullanılan kitapların genel özellikleri ortaya konarak olumlu ve olumsuz yönleri belirlenmiştir. Yapılan farklı analizler sonucunda Yedi İklim ve İstanbul kitaplarının diğer kitaplara göre artı yönlerinin olduğu görülmüştür.
\end{abstract}

Anahtar sözcükler: Türkçe eğitimi; ders kitapları; yabancılara Türkçe öğretimi; Rasch analizi

\section{AUTHOR BIODATA}

Nurşat Biçer, completed his doctorate degree in Turkish teaching as a foreign language at Atatürk University. He works as an associate professor at Kilis 7 Aralık University, Department of Turkish Language and Social Science Education. His fields of study Turkish teaching as a foreign language, bilingualism, qualitative research. He is interested language teaching to refugees people.

Veli Batd1, works as an associate professor at Kilis 7 Aralık University, Department of Curriculum and Instruction. His studies are especially related to teacher education, graduate education, English teaching/learning, curriculum evaluation. He makes use of many statistical programs such as meta-analysis, meta-thematic analysis, Rasch Measurement, NVIVO, Maxqda and SPSS programs. 